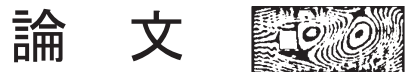

\section{都市乱流境界層における建物壁面風圧と周辺気流に関する Large-Eddy Simulation Effect of Turbulent Flows Generated by Simplified Roughness Blocks on Instantaneous Wall Pressure Based on Large-Eddy Simulation}

\author{
池谷直樹*1 \\ 廣瀬智陽子 $* 2$ \\ 萩島 理*3 \\ 谷本 潤*4 \\ Naoki IKEGAYA, \\ Chiyoko HIROSE, \\ Aya HAGISHIMA, \\ Jun TANIMOTO
}

\section{SUMMARY}

We have performed Large-Eddy Simulation of flow and pressure fields over two types of urban-like block arrays in order to investigate the relationships between instantaneous building wall pressure and surrounding flow fields. The adopted block arrays are: lattice-type square and staggered pattern. The analysis on the distributions of statistics for wall pressure shows that the large values of the statistics are observed along with the top and side edges of the wall for the square array, whereas they are shown on an upper half region of the wall for the staggered array. These large values are due to air flow introduction from both above and side of the target block for square array; in contrast, strong flows introduced into canopy area cause large pressures of the upper half of the wall for staggered array.

key words: pressure coefficient, urban-like array, large-eddy simulation

\section{1.はじめに}

室内の空気質や温熱快適性などの室内環境改善方法の 一つとして, 近年の省エネルギ一意識の高まりから, 機 械的な動力を必要としないパッシブな自然換気に注目が 集まっている。一般に自然換気には，建築物に設置され
た十分小さな換気開口や隙間前後の静圧差によって行 われる換気（漏気）と，大きな開口前後の静圧差と流 入空気の動圧による通風換気の二つがある。また，そ の換気ポテンシャルに応じて, 温度差により生じる密 度差が原因となる場合を温度差換気，壁面近傍風速か

\footnotetext{
*1 九州大学大学院総合理工学研究院 助教

Assistant Professor, Interdisciplinary Graduate School of Engineering Science, Kyushu University

$* 2$ 三菱電機（当時九州大学大学院大学院生）

Mitsubishi Electric Corporation

*3 九州大学大学院総合理工学研究院 准教授

Associate Professor, Interdisciplinary Graduate School of Engineering Science, Kyushu University

*4 九州大学大学院総合理工学研究院 教授

Professor, Interdisciplinary Graduate School of Engineering Science, Kyushu University

（原稿受理年月日：2016年2月19日，採用決定年月日：2016年9月5日）
} 
ら動圧から静圧に変換されることで生じる差圧に起因す る換気を風力換気と分類されている1。本論では特に, 風 力換気について取り扱う。

風力換気の推定においては, 従来から開口が十分に小 さく, 開口流入後に気流が完全に散冕するという仮定を 置くことで, ベルヌーイの定理を適用した換気量推定が 行われてきた。すなわち，換気量は開口がない条件にお ける壁面風圧係数と開口部抵抗を意味する流量係数によ って求めることが可能である。その際の建築物の風圧係 数や流量係数は, 風洞実験等によって経験的に求められ ている。ベルヌーイの定理を適用していることから明ら かなように，この推定方法はあくまで開口が微小で室内 に流れ込む気流が内部で完全散冕できる程度であること に加えて，定常状態であることを前提にしている。その ため，実際の換気量に影響しているであろう非定常気流 の影響を含めた積算換気量をこの推定方法で見積もるこ とは難しいと思われる。そこで，近年では Large-Eddy Simulation（LES）による数值計算を用いた非定常換気量 の推定も行われ始めている。たとえば， Jiang et al. ${ }^{2)}$ は, 片側開口における換気量推定において, 非定常成分の寄 与が大きく, 平均換気量だけでは正味換気量を過小評価 してしまうことを指摘している。ほかにも, Hu et al. . $^{3)}$ は,

LES の特性を生かし，二開口建物を対象として，開口に 対する風向を変化させた際の瞬時換気量が時間的に劇的 に変化することを示している。

このような定常・非定常を含めた換気量推定に関する 研究が数多く報告されているが，対象とする建物は単体 として取り扱われ，都市内部に位置する建物の周辺状況 が十分に再現されていない場合が多い。これは，実際の 都市内部の建築物は, 複数の他の建築物から構成される 都市粗度群内に位置しているものの, ある程度対象を限 定して切り出し, 周囲の環境を境界条件として表現する ことで，問題を単純化し実用的な換気量推定が行えるよ うな方法を執っているからであろう。すなわち，室内側 の空気環境を取り扱う場合は, 粗度周辺気流など外的要 因はいわば境界条件として対象の系に付与され，それよ りも小さなスケールを換気量推定の対象としていると観 ることができる。

その一方で, 都市内建物群により形成される周辺気流 場やそれにより発達する乱流都市境界層に関する研究も 多く進められている。古いものでは, 粗度密度に応じて 粗度周辺気流場が，粗度に干渉されない Isolated Flow か ら徐々に互いに干渉される Wake Interference Flowを経て, 高密度状態での Skimming flow に遷移すると説明した
Oke ${ }^{4)}$ の Flow Regime がよく知られている。この Flow Regime は, 単に粗度周辺気流の名称を定めただけではな く, 粗度密度に応じて粗度周辺気流が干渉し, 平均流の 異なる気流場が形成されることを示したもので, 粗度周 辺気流の特徵を良く反映していると考えられている。そ のため, 今では良く知られている立方体粗度群に作用す る抗力係数と密度が上凸分布の関係 ${ }^{5)}$ となることも, この Flow Regime 遷移と良く対応することが知られている 。 また, 歩行者空間風速と都市の粗度密度との関係に着目 した研究もあり, 歩行者高さ風速が粗度密度に応じて減 衰する関数として種々提案されている7 10)。以上より, 対 象粗度周辺の定常気流場が如何に粗度密度と密接に関係 しているかがわかるだろう。それに加えて，都市特有な 非定常気流場の発生も知られている。たとえば，元々滑 面境界層で観測されていたような突発的な上昇流や下降 流である sweep / ejection 現象は, 粗面でもその上空で同 様に観測されることが知られるようになり ${ }^{11)}$,さらには, 植生キャノピー層上空 ${ }^{12)}$, や都市キャノピー上でも発生

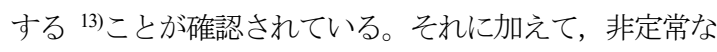
乱流現象によって, キャノピー内スカラー放出が促進さ

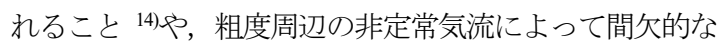

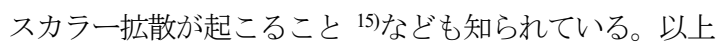
のような事例からも, 都市乱流境界層では, 非定常気流 場が形成され，その一因として都市内建物群の幾何形状 が作用していることも十分理解できる。

このように, 対象建物の換気量推定と屋外空気環境で ある都市境界層の気流場の影響は, これまでの研究では 室スケールを境界としてそれぞれ独立に多くの研究がな されてきたと言える。しかしながら, 都市内に存在する 建物に対して, 都市乱流境界層の特性を反映した風力換 気量を精度良く推定するためには, 都市スケールと室内 スケールを建物壁面を境界として分離せずに，両スケー ルを同時に解析寸ることが必要であると考えられる。そ れに加え, 都市内部で発生する非定常・非一様な気流場 の特性を考慮すると, これまでに得られているような平 均風圧係数の幾何依存性だけではなく, 非定常な変動風 圧係数に着目寸る必要がある。従って, 都市境界層のよ うな周辺気流と室内の非定常気流場を同時解析する

coupling simulation を行うことが望ましいと思われるが， 数オーダー異なる室・屋外スケールを対象とした気流場 を同時解析することは, 計算機資源の制約上, 非常に困 難である。そこで, 本研究では, 都市境界層内に位置す る建築物に対する換気量推定において, 室スケール側の 境界条件となる壁面変動風圧係数が都市境界層内気流場 
によってどのように変動しているかを明らかにすること を目的として, 非定常解析が可能な LES を適用した立方 体粗度周辺気流場解析を行う。得られた気流場と壁面圧 力の相関関係を定量的に示し, 壁面風圧に影響する建物 周辺気流特性を解明することを試みる。

\section{2. 解析条件}

図 1 に対象とする解析領域の模式図を示す。座標系は, 主流方向, スパン方向, 鉛直方向をそれぞれ $x, y, z$, 対応する風速成分を $u, v, w \quad\left(u_{i}, i=1,2,3\right)$ と定義す る。解析対象は, 一辺 $H(=24 \mathrm{~mm})$ の立方体粗度を建蔽率 $25 \%$ （粗度屋根面積と平面積の比）で規則的にに配列し た二種類の粗面が形成する乱流境界層とする (図 1 整形 配列 SQ，千鳥配列 ST)。

計算領域は $4 H \times 4 H \times 4 H$ とし, 主流, スパン方向に周 期境界条件を課すことによって, 同じ配列で無限に粗度 が整列された系を再現している。各方向について，等間 隔の構造格子を採用し, グリッドサイズを $H / 16$ としてい る。上空境界条件には, Free-slip 条件, 地表面境界及び建 物壁面境界にNo-slip 条件を適用し, 流れは主流方向のバ ルク風速 (yz 断面内平均風速) $U_{b u l k}=4.5 \mathrm{~m} / \mathrm{s}$ が一定 となるような圧力勾配 $d p / d x=-\rho u_{\tau}^{2} / \delta$ を動的に決定 し, 体積力として Navier-Stokes 方程式に付加している。 $\delta$ は解析における境界層高さで, 計算領域高さ $4 H$ と同じと なる。また, 時間ステップは平均クーラン数が 1 以下に なるように, $d t=2 \times 10^{-4} \mathrm{~s}$ で, 一定值を設定している。 数值解析には, 非圧縮系における連続の式および空間 Filter された Navier-Stokes 方程式を対象とした LES を採 用し, オープンソース CFD 解析ツールである OpenFOAM-2.1.1 を用いて行った。LES の Sub-grid scale (SGS) モデルには標準 Smagorinsky モデル 16)を適用した。 データ取得については，主流方向時間平均風速と Reynolds 応力の水平面内平均鉛直プロファイルを 10 秒ご とに確認し, 各プロファイルの差がそれぞれ $1 \%$ 以内（風 速), $5 \%$ 以内（レイノルズ応力）となるまでの期間を統 計值が定常となるまでの助走時間としている（ 110s）。 それ以降の 30 秒間を解析時間とした。これらの時間は, Coceal et al. ${ }^{17)}$ により提案されている助走期間と解析期 間の基準值である， $200 T （ T=H / u_{\tau}$ は基準時間）と $400 T$ をそれぞれ満たしている。また, 速度および圧力 の取得周波数は，いずれも $1000 \mathrm{~Hz}$ とした。

本報の数值解析については, 計算条件の設定に関する 検証は行っていないが, 既往研究 ${ }^{17) 18)}$ に基づき, 都市乱 流境界層の統計量が十分再現できるよう注意深く計算条 (a)

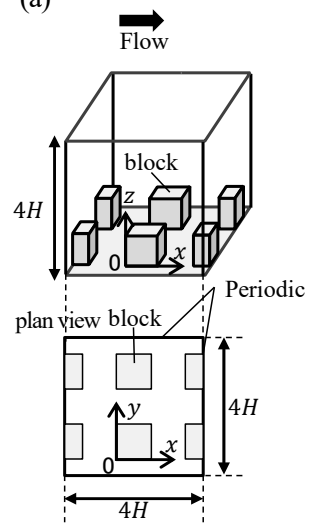

困 1 計算領域の模式成 (b)

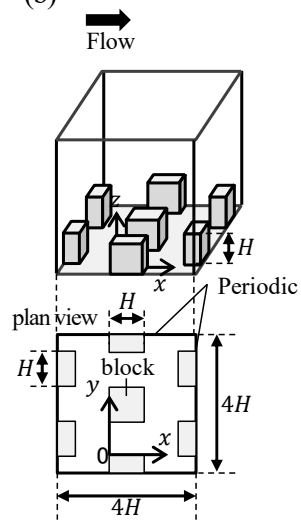

Fig. 1 Schematics of simulation domain

(a) Square SQ (b) Staggered ST

件を決定した。すなわち, 計算領域の大きさについては, Coceal et al. ${ }^{17)}$ が示した $4 H \times 4 H \quad$ と $8 H \times 8 H$ の水平断面 を持つ計算領域を対象とした Direct Numerical Simulation

（DNS）の結果から，今回採用した $4 H \times 4 H$ の水平方向 計算領域でも, 粗度上空とキャノピー内の平均風速とレ イノルズ応力に差異が見られないことに基づき, 計算負 荷低減のために最小の水平方向の計算領域を設定した。 加えて, 計算領域高さについても, Coceal et al. 17) によ る高さ $4 H$ と $8 H$ の計算領域で得られたキャノピー上部及 びキャノピー内の無次元平均風速と無次元レイノルズ応 力に差異が見られないことを参考に, 高さ $4 H$ を採用して いる。さらに, Xie and Castro ${ }^{18)}$ により, $4 H \times 4 H \times 4 H$ の 計算領域において, 風洞実験により得られた平均壁面風 圧係数を良く再現できることが報告されていることから， 本報の評価対象のひとつである壁面風圧についも，この 計算領域での解析が許容範囲であると考えられる。その 一方で, Coceal et al. ${ }^{17)}$ で指摘されているように, 実際に 十分に長く粗度が設置されている条件に比べて, 周期境 界条件を課した小さな計算領域では，ストリーク構造の ような大規模な乱流構造が再現されないことが予想され る。そのため，本報で採用している解析領域では，大規 模乱流構造に起因寸ると考えられる風圧変動は評価でき ないことになるが，まずは，粗度周辺流れと変動風圧と の関係を評価することを目的として, $4 H \times 4 H \times 4 H$ の計算 領域での解析を行うこととした。また, 格子解像度につ いては, Xie and Castro ${ }^{18)}$ が示しているH/16を採用した。 Xie and Castro ${ }^{18)}$ は, 格子解像度として, H/8 からH/64 で得られた立方体粗度周辺の統計值を比較し，鉛直方向 
標準偏差に見られる粗度上部でのピーク值を再現するた めには, $H / 32$ 以上の解像度が必要であることを指摘し ているが，主流およびスパン方向の標準偏差や粗度表面 に作用する風圧分布については, 解像度 $H / 16$ で実験結 果を十分再現できることを示している。本解析の主たる 目的は，換気ポテンシャルである壁面圧力が，周辺気流 場にどのように影響されるかを解明することであるため, より高い解像度での解析が望まれるものの, 計算資源の 制約から壁面圧力プロファイルが十分再現できると思わ れる $H / 16$ での解析とした。なお，解析結果による気 流場と粗度壁面圧力の妥当性検証については，3．1 節 に報告する。

3. 結果

3. 1 既往研究との比較

はじめに，気流場の再現性を確認するため，時間平均 速度プロファイルと抗力係数について, 既往研究による 風洞実験および数值計算の結果と比較を行う。

図 2 には，千鳥配列における水平面内 4 点の時間平均 速度プロファイルの平均值と, 同配列条件における風洞 実験により得られた結果を示している (Xie and Castro ${ }^{18)}$ より転載)。また，風速の規格化には Coceal et al ${ }^{17)}$ により 提案されている有効摩擦速度 $u^{*}=u_{\tau}(1-d / \delta)^{0.5}$ を用 い, ゼロ面変位 $d$ には, Cheng and Castro ${ }^{19)}$ の結果 $d=$ $0.83 H$ を採用した。これは, 境界層が自然発達する風洞 実験とは異なり, 数值計算では圧力勾配駆動による体積 力が作用していることに応じて, 対数領域における速度 プロファイルのスケーリング速度が変化することを考慮 したものである。粗度上空の境界層内において, 既往研 究の結果とよく一致していることが確認できる。また, 風速の標準偏差三成分および鉛直方向レイノルズ応力に ついは, 既往研究 ${ }^{18)}$ の結果と比較し, 主流方向, 鉛直 方向標準偏差，および鉛直方向レイノルズ応力は良く一 致することを確認している ${ }^{20)}$ 。一方で，スパン方向標準 偏差については, 本解析の結果が風洞実験に比べて, 一 割程度過小となったものの, Xie and Castro ${ }^{18)}$ による同じ 計算領域と格子解像度での LES でも同じ傾向が見られる ことから，計算領域の大きさや境界条件などの風洞実験 と数值解析の解析条件の差異に原因があると考えられる。 以上より, 千鳥配列における粗度上空統計值については, 実験結果を良く再現していると言える。整形配列につい ては，参照となるデータが無いため検証していない。

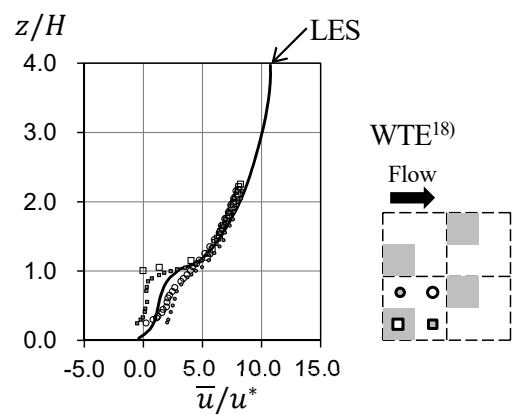

図 2 主流方向速度プロファイルの風洞実験[文献 ${ }^{18)}$ よ り転載]との比較。

Fig.2 Comparison of streamwise wind speed profiles of LES and WTE [reprinted form ${ }^{18}$ ]. (a)

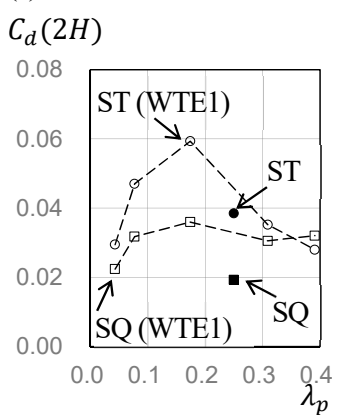

(b)

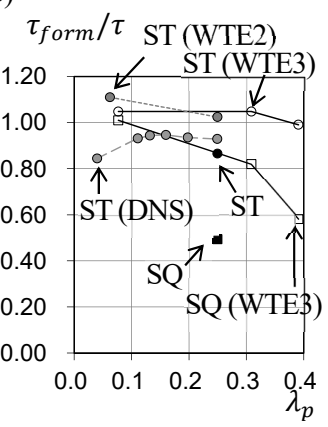

図 3 バルクパラメータの比較 (a) 抗力係数 (b) 形状 抵抗比率 WTE1 ${ }^{6}$, $, \mathrm{WTE}^{24)}, \mathrm{WTE}^{22)}, \mathrm{DNS}^{23)}$

Fig. 3 Comparison of bulk parameters (a) drag coefficient (b) ratio of form drag to total drag. $\mathrm{WTE}^{6)}$, WTE2 ${ }^{24)}, \mathrm{WTE}^{22)}$, $\mathrm{DNS}^{23)}$

次に, 数值計算および風洞実験における抗力係数 $C_{d}$ を 比較することで, 正味運動量吸収の再現性について考察 する。図 3 (a) には, 次式で定義した抗力係数を示した。

$$
C_{d}(2 H)=\frac{\tau}{0.5 \rho u_{2 H}^{2}}
$$

ここで, $\tau$ は全抗力, $\rho$ は空気密度, $u_{2 H}$ は高さ $2 H$ に おける水平面内平均風速である。既往の風洞実験の結果 6)によれば, いずれの配列でも, 建蔽率の増加に対して, 粗度周辺の気流場が Isolated Flow から Wake Interference

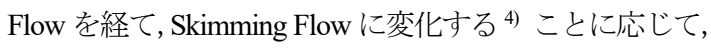
建物ひとつ当りに作用する形状抵抗が単調减少する効果 と, 粗度立面積が増加する効果が重畳されて, 抗力係数 $C_{d}$ は建蔽率 $\lambda_{p}$ に対して上凸の分布を示す。しかし, 粗度の 配列方法によって，特に中程度の建蔽率において，それ ぞれの粗度に作用する形状抵抗の差が顕著になるため, 抗力係数の差が大きくなると考えられている。図 3 (a) に 示した通り, 千鳥配列の抗力係数が整形配列に比べて大 
きくなるのは，粗度の主流方向間隔が広いため, 整形配 列に比べて粗度に作用する形状抵抗が大きくなるからで あると考えられる。本数值解析結果を見ると, 整形配列 よりも千鳥配列の抗力係数が大きくなる点については定 性的には再現されている。しかし，風洞実験では同じ建 蔽率での測定結果がないため直接的には比較できないも のの, 本解析による抗力係数 $C_{d}$ は, 近傍の風洞実験結果 を線形補間した值と比較して，千鳥配列で約 $25 \%$ ，整形 配列では約 40\%の過小評価となっている。一方で，図 2 に示した通り有効摩擦速度 $u^{*}$ で規格化した速度プロフ アイルは良く一致している。このことは，単に全抗力が 過小になっているというだけではなく, 流れの駆動方法 や計算領域が参照としている風洞実験と異なることも原 因であることを意味していると考えられる。すなわち， 本解析では周期境界条件を課すことで同配列が主流およ び主流直交方向に無限に繰り返された配列を再現してい るため, 流れの駆動力として領域に一定の圧力勾配を付 加している。また, 計算領域高さは, Coceal et al. ${ }^{177}$ の報 告を参考にした上で, $4 H$ としている。これらの計算条件 のため, Coceal et al. が指摘しているように, 有効摩擦速 度 $u^{*}=u_{\tau}(1-d / \delta)^{0.5}$ がスケーリング速度となると 考えられる。実際に, 本報やCoceal et al. ${ }^{17)}$ に示されてい るように, 有効摩擦速度による無次元化により, 風洞実 験と良く一致することが分かり，定圧力勾配下では，全 駆動力により定義する摩擦速度ではなく, ゼロ面変位 $d$ と計算領域高さ $\delta$ によって補正した有効摩擦速度 $u^{*}$ に よる無次元化が適切であることが分かる。言い換えれば, 定圧力公配下で駆動した気流場は, $(1-d / \delta)^{-0.5}$ 倍にな り，風洞実験に比べて同じ高さにおける風速が加速され ていることを意味する。従って, 本解析における抗力係 数は風洞実験に比べて $(1-d / \delta)$ 倍（約 $21 \%$ ）に過小評 価されることになる。この補正量を考慮すれば，千鳥配 列における抗力係数の約 $25 \%$ の過小評価は駆動力と計算 領域の高さの影響が大きいと考えられる。一方で, 整形 配列については，この補正量を考慮したとしても，抗力 係数の過小評価は依然約 $20 \%$ と大きくなるため, 計算条 件以外の要因も影響していると思われるが，今のところ その原因は分かっていない。

続いて, 粗度に作用する形状抵抗 $\tau_{\text {form }}$ と全抗力 $\tau$ の 関係について考察する。粗面群に作用する全抗力 $\tau$ は, 粗度に作用寸る前後面圧力差による形状抵抗 $\tau_{\text {form }}$ と， 粗度表面や床面などの固体表面に作用寸る摩擦抗力の和 であるが, 都市境界層を対象と寸るような Re 数が十分に 大きい場合, 粗度に作用寸る形状抵抗 $\tau_{\text {form }}$ が支配的に
なることから, Fully Rough Regime に遷移することが知ら れている。Snyder and Castro ${ }^{21)}$ によれば, 粗度 Re数 $\mathrm{Re}^{*}=$ $u^{*} z_{o} / v>O(1) \quad\left(z_{o}\right.$ : 粗度長, $v$ : 動粘性係数) 程度で fully rough になると言われている。本報での解析対象は, 粗度 長を $H / 10$ 程度として見積もると, $R e^{*} \sim 10$ 程度になる ため, 固体表面の粘性抵抗に直接的に影響する壁面境界 条件は, 気流場や全抗力に対して強く影響を及ぼさない と考えられる。実際に，Xie and Castro ${ }^{18)}$ は，本解析と同 程度の風洞実験スケールにおける千鳥配列上の乱流境界 層の LES とDNS において, 固体壁境界条件として, No-slip と壁関数の二条件での解析に対して気流場に大き な差が生じないことを報告している。本解析については, 壁面境界条件の影響に関する検証は行っていないが，以 下では, 形状抵抗比率 $\tau_{\text {form }} / \tau$ を算出し, 既往研究結果 と比較する。

図 3 (b) には, 本計算と既往研究における形状抵抗比率 $\tau_{f o r m} / \tau$ と建蔽率 $\lambda_{p}$ の関係を示した。既往の風洞実験で は, 粗度の風上面および風下面に設置した多点圧力孔に より計測した形状抵抗 $\tau_{\text {form }}$ と, 浮体上に設置された可動 式粗面に直接歪みセンサーを取り付けることで計測した 全抵抗ての結果が報告されている（Zaki et al. ${ }^{22)}$ (整形,

千鳥), Cheng and Castro ${ }^{19)}$ (千鳥)）。加えて, Leonardi and Castro ${ }^{23)}$ によるDNS の結果も示している (千鳥)。風洞 実験の結果について, 千鳥配列ではどの建蔽率において も形状抵抗比は 1.1 0.99 の值を示している。これは, 個々 の粗度に作用する形状抵抗が非常に小さいため, 測定值 を積算して平均形状抵抗を推定する際に誤差が蓄積した 結果，全抗力よりも大きくなってしまう場合があるため であると思われる。また, Zaki et al. ${ }^{22)}$ の風洞実験で使用 されている圧力センサーは, Full scale レンジに対して, $0.2 \%$ の精度保証のもので, 風圧係数に換算して約 $\pm 6 \%$ の 測定誤差が含まれるものと考えられるため, 機器の精度 も影響していると考えられる。DNS の結果では, 最大で 約 0.95 程度 $\left(\lambda_{p}=16 \%\right)$, 最小で 0.84 程度 $\left(\lambda_{p}=4 \%\right)$ の形状抵抗比になっていることから，風洞実験での形状 抵抗比は一割程度は過大に推定されている可能性が高い。 いずれにしても，千鳥配列において形状抵抗が支配的で あることは，DNS および風洞実験の両者で良く確認され ている。これに対し, 本解析の千鳥配列の結果は, 形状 抵抗比率が約 0.87 であり, 風洞実験と同様に形状抵抗が 支配的であることに加え, 比率も DNS の結果に非常に近 い。このことから，比較的粗い解像度 $H / 16$ を採用し， 固体面境界条件として形式的にNo-slip 条件を課している ものの，それが気流場や全抵抗力に及ぼす影響は非常に 
小さいことが予想される。その結果として運動量吸収量 がよく再現されているため, 図 2 に示したように粗度上 空の平均速度プロファイルが非常に良く一致していたの だと推測される。一方で, 整形配列の場合, 風洞実験の 結果では高密度になるほど形状抵抗比率が減少し, 建蔽 率約 $40 \%$ において最小となり，0.6 程度を示している。今 回の LES における形状抵抗比は, 建蔽率 $25 \%$ であること から，これよりも大きな值となることが予想されるが， 形状抵抗比は 0.5 程度を示している。千鳥配列における風 洞実験と DNS の比較から, 風洞実験結果は, センサ一精 度上，約 $\pm 6 \%$ 誤差は見込まれるが，その分を加味して も数值解析における形状抵抗が過小評価されていると言 える。整形配列の場合, 粗い解像度を採用したことでキ ヤニオン内の気流が十分に再現されず，壁面圧力が過小 評価された結果, 形状抵抗比が風洞実験よりも小さくな ったことが要因のひとつとして考えられる。

以上のことから，千鳥配列については風洞実験に非常 に近い気流場が再現されていると予想される。一方で, 整形配列については, 抗力係数や形状抵抗比をより高精 度にを再現するためには, 壁面境界条件や格子解像度な どの計算条件について別途検証することが望まれる。し かし, 現状得られる参照データが不足していることや, 本報における主題が都市境界層による乱流場と壁面圧力 が如何に連動しているかを示寸目的であることから, 整 形配列についてはこれ以上の再現精度検証は行わずに, 以上の数值解析結果に基づいて, 非定常気流場と壁面圧 力分布の関係について分析を進める。

3. 2 壁面前面風圧の統計的性質

はじめに, 粗度風上面における風圧力の空間分布とそ の時間的ばらつきについて考察するため, 風上面風圧の 面平均值 $\left\langle\overline{p_{f}}\right\rangle \quad(\langle\cdot\rangle$ は粗度表面の平均）と各点の壁面圧 力 $\overline{p_{f}}\left(\bar{\phi}=1 / T \int_{T} \phi(t) d t\right.$ : 時間平均値 $)$ との差を空間 差压 $\Delta p=\overline{p_{f}}-\left\langle\overline{p_{f}}\right\rangle$ と定義し, $\Delta p$ に対する統計值とし て, 時間平均値 $\overline{\Delta p}$, 標準偏差 $\sigma_{\Delta p}$ および歪み度 $S_{\Delta p}$ を算出した。時間平均值および標準偏差については, 参 照高さ $2 H$ における動圧で無次元化している。図 4 に整形 配列および千鳥配列における各統計值を示した。また， 図中の $y_{b}, z_{b}$ は粗度辺を示寸座標である。

まず, 整形配列の場合, 時間平均空間差圧 $\Delta p$ は粗度 風上面の外縁に沿って大きな值を示している。それと対 応するように, 空間差圧の標準偏差 $\sigma_{\Delta p}$ (図 4(c) ) や歪 み度 $S_{\Delta p}$ (図 4(e)）も風上面外縁に沿うように大きな值 を示している。建蔽率 $25 \%$ の整形配列においては, 粗度 上空気流が粗度上部をかすめる程度でわずかにしかキャ
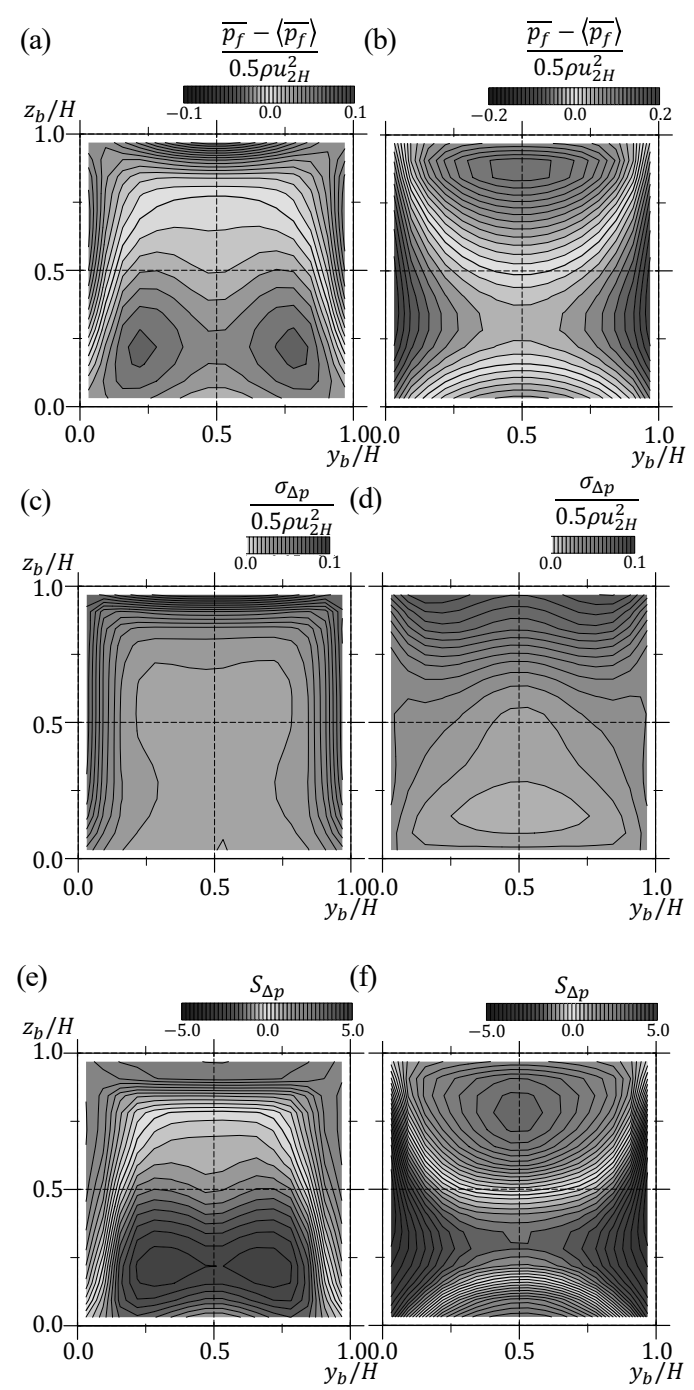

図 4 粗度前面風圧の統計值 (a), (b): 平均, (c), (d): 標 準偏差, (e), (f): 歪夕度 (a), (c), (e): 整形配列, (b), (d), (f): 千鳥配列。

Fig. 4 Statistics of pressure on a front wall (a), (b): mean, (c), (d): standard deviation, (e), (f): skewness. (a), (c), (e):

$$
\text { SQ, (b), (d), (f): ST }
$$

ニオン内に導入されない skimming flow が形成されてい るため, 粗度上部での大きな空間差圧 $\Delta p$ は, 風速の大き な主流方向気流が粗度風上面上部に衝突することが要因 となっていると予想される。それに加えて，整形配列で は主流方向に見通すことができる街路が存在し, キャニ オン内でも速い主流が維持されている。そのため, 風上 面の左右両側でも空間差圧が大きくなったのだと考えら れる。また, 空間差圧が大きな場所において標準偏差 $\sigma_{\Delta p}$ や歪み度 $S_{\Delta p}$ が大きいことは, 粗度上空や街路など比較 
的速い風速が維持された流体塊が風上面外縁に沿って衝 突することで壁面圧力を大きくするだけではなく, それ に合わせて壁面圧の変動も大きくなることを示している。 さらに, 歪み度が正に大きくなっていることから, 高速 流が衝突することで壁面圧力が大きくなる事象は, 間欠 的に発生していることが示唆される。

千鳥配列についても, 平均空間差圧 $\Delta p$, 標準偏差 $\sigma_{\Delta p}$ および歪み度 $S_{\Delta p}$ がそれぞれ粗度上部において大きな 值を示している点では共通しており，上空からの高速流 の取り込みにより壁面差圧が大きくなることに加えて, その場所での時間的変動も大きくなることを示している。 しかし, 整形配列の場合とは異なり, 千鳥配列において 空間差圧が大きな值を示すのは, 粗度風上面の $y_{b}=0.5 H$ 付近において, 高さ $z_{b}=0.5 H \sim 1.0 H$ で, 鉛直方向に広 い. これは, 千鳥配列の場合, 整形配列に比べて主流方 向粗度間距離が長いため, Flow Regime が Wake Interference $\mathrm{Flow}^{4)}$ に近いために，キャニオン内に上空空 気が導入されやすいためであると予想される。また, 整 形配列で観られたような風上面外縁に沿うような分布は 観測されていない。これは, 粗度が交互に配列されてい るため, 粗度両側におけるキャニオン内風速は減速され るためであると考えられる。

\section{3 非定常壁面風圧変動と周辺気流場の関係}

続いて, 瞬時速度分布と風上面圧力分布から, 粗度周 辺気流と壁面圧の非定常変動の関係性について考察する。 図 5(a-1), (a-2) には, 高さ $z=0.5 H$ における $x y$ 断面内 風速分布と紙面垂直方向風速を示した. ベクトルは, 主 流方向に位置する二つの粗度間 $(1.0<x / H<2.0,0.0<$ $y / H<1.0)$ のみを示している。図 5 (b-1), (b-2) には, 対象粗度風上面の空間差圧と最近傍格子における風速分 布を示している。また, 図 5 において, (a-1)と(b-1), (a-2) と(b-2)は，特徵的な瞬時気流場が見られた同じ時刻にお ける結果を示している。なお, 参照風速は高さ $2 H$ におけ る水平面内平均風速 $u_{2 H}$ とし, それぞれ無次元化してい る。

整形配列においては，空間差圧分布から推測されるよ うに, 粗度上空および粗度両側から間欠的に気流が導入 されることによって, 壁面風圧が大きくなると考えられ る。図 $5(\mathrm{a}-1)$ には, $y / H=1.0, x / H=1.5 \sim 2.0$ の付近で, スパン方向から気流が粗度間に取り込まれている様子が 見られる。また, 図 5(a-2)では, $y / H=0, x / H=1.5 \sim 2.0$ 付近から, 粗度間に気流が取り込まれている。これらの スパン方向の気流の取り込みに応じて, 図 5(b-1)では $y / H=1$ 付近で, 図 5(b-2) では $y / H=0$ 付近で, 粗度
風上面風圧が増加していることが確認できる。興味深い のは，スパン方向気流の取り込みは，どちらか一方から 発生していることである。図 4 に示した時間平均空間差 圧や, 既往研究で得られているような時間平均壁面風圧 係数 ${ }^{22244}$ は左右対称な分布となることが知られているが, 瞬時分布は対称形にはならず, どちらか一方から導入さ れた空気塊によって間欠的に壁面圧力が大きくなってい ることが良くわかる。粗度風上面外縁部において間欠的 に壁面圧力が大きくなることは, 図 4 (e) に示した歪み度 の分布とも整合している。

整形配列の空間差圧の分布では, 粗度風上面上部でも 大きな值が確認ており，この点についても瞬時気流場と の関係が予想される。そこで, 図6(a)には, 粗度スパン 方向中心の xz断面における速度ベクトルと紙面垂直方向 風速を示した。ベクトルは, $1.0<x / H<2.0,0.0<$ $z / H<1.0$ の範囲のみを示している. また, 同じ時刻に おける対象粗度風上面の瞬時圧力分布と最近傍格子にお ける yz 断面速度ベクトルを図 6(b) に示した。図から明 らかなように, 粗度上空から鉛直方向に気流が導入され, その結果粗度上部での壁面圧が大きくなる様子が見られ る。しかし, 主流が粗度風上面に衝突するというよりは, Skimming Flow に近いような粗度上部をかすめる流れが 形成されることにより, 結果として弱い下降流が生じる ため, 壁面圧が大きくなるのは粗度上部の限られた領域 に留まっている。

図 7(a) には, 千鳥配列の $y / H=0.5$ における xz断面 の速度ベクトルとスパン方向風速を示している。ベクト ルは, $z / H<1.0$ のみを示した。また, 図 7(b)には, 対 象粗度風上面の空間差圧と最近傍格子における風速分布 を示している。千鳥配列の場合, 主流方向粗度間距離が 長いため, 整形配列に比べて上空風のキャニオン内への 取り込みが容易に発生する。図7 (a) では, $x / H=0 \sim 1$ 付 近の領域ですでにキャニオン内に向かって流れる気流が 形成され，そのまま風下側に位置する粗度風上面に衝突 していることがわかる。結果として, 図 7 (b) に示寸よう に, 高さ $z / H=1 \sim 0.5$ に渡って壁面圧力が大きくなって いる。

また, 整形配列の場合と同様に, 大きな壁面圧力分布は, 気流の変化に合わせて間欠的に発生していることが予想 される。図 $8(\mathrm{a}-1)(\mathrm{a}-2)$ には, 左右の粗度隅角部における 壁面圧力が大きくなった異なる時間におけるの高さ $z / H=0.5$ の $\mathrm{xy}$ 断面における速度べクトルと鉛直風速 を示している。ベクトルは $y / H<1.0$ の範囲のみを表示 している。また, 図 $8(\mathrm{~b}-1),(\mathrm{b}-2)$ には, 対象粗度風上面に 
(a-1)

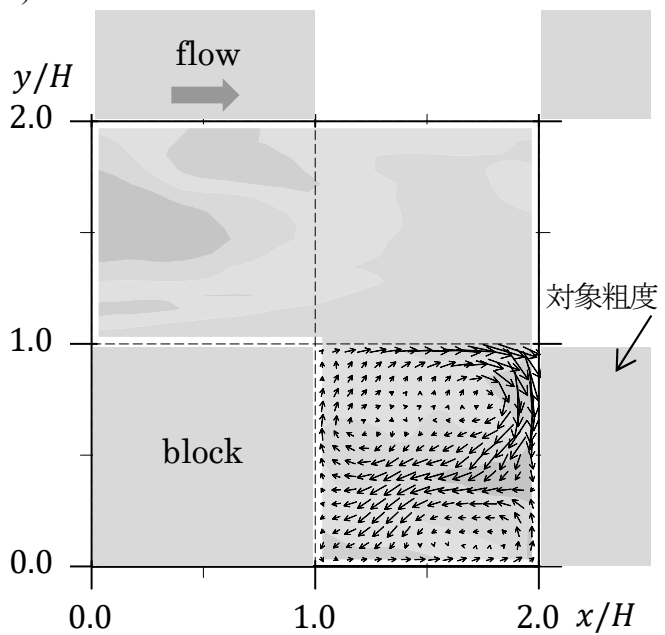

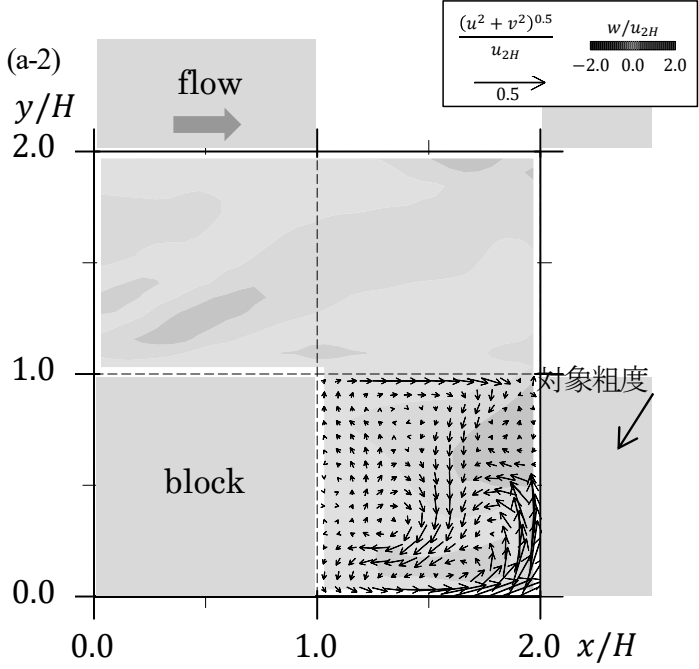

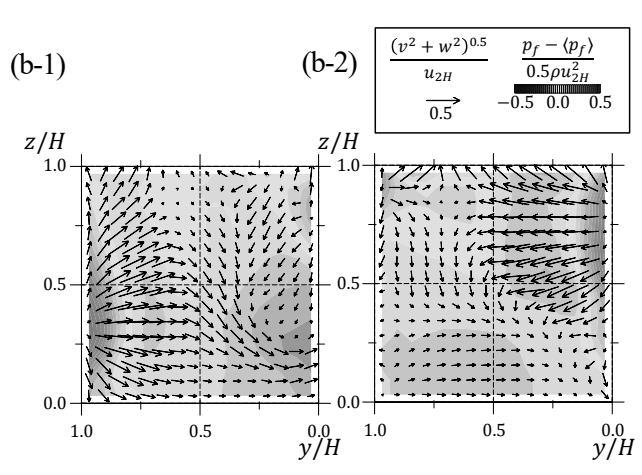

(a)

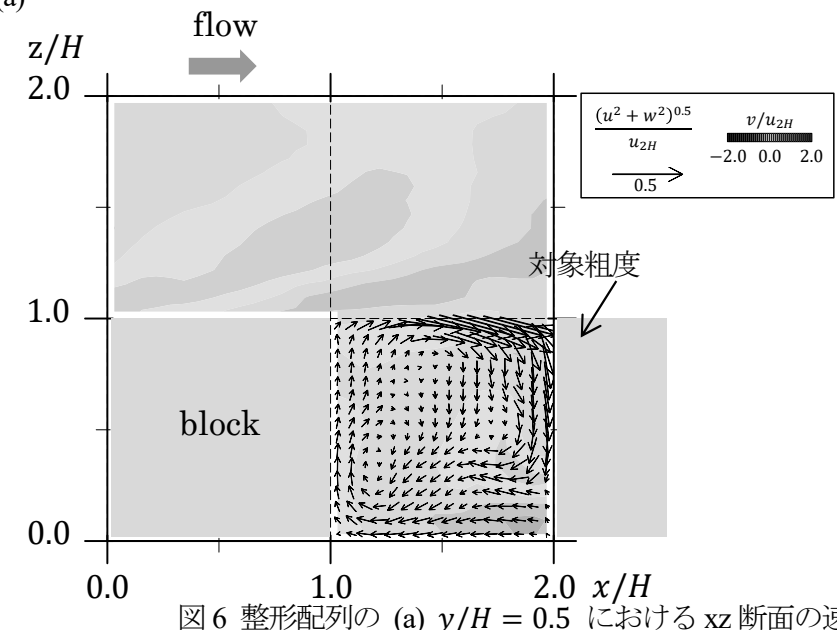

(b)

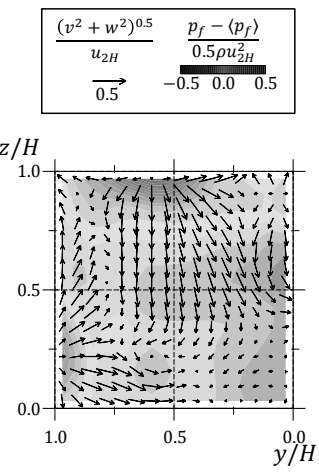

図 6 整形配列の (a) $y / H=0.5$ における $\mathrm{xz}$ 断面の速度ベクトル*とスパン方向風速

(b) 対象粗度風上面の最近傍格子における yz 断面の速度べクトルと瞬時前面壁面圧力

*ベクトルはキャニオン内 $(1.0<x / H<2.0,0.0<z / H<1.0)$ のみを示している。

Fig.6 Instantaneous vector and contour of $x z$ cross section at $y / H=0.5$ and (b) instantaneous vector* at the first grid from the front wall of the target blocke and contour of the wall pressure. *Only shown in the area between two blocks $(1.0<x / H<2.0,0.0<z / H<1.0)$ 
(a)
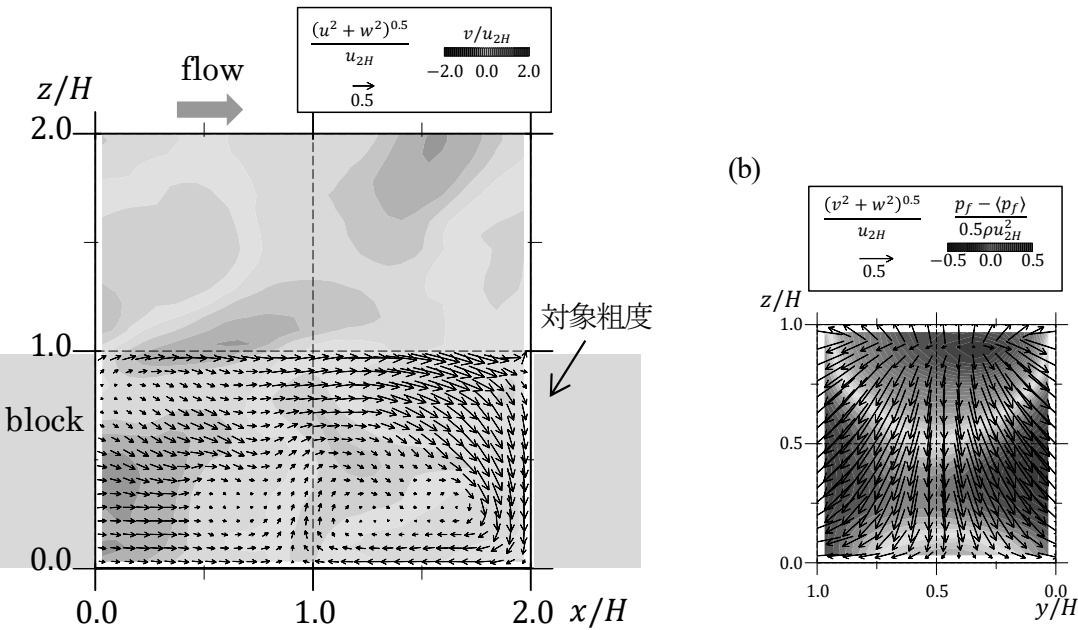

図 7 千鳥配列の (a) $y / H=0.5$ における xz 断面の速度ベクトル*とスパン方向風速

(b) 対象粗度風上面の最近傍格子における yz断面の速度ベクトルと瞬時前面壁面圧力

*ベクトルはキャニオン内 $(0.0<x / H<2.0,0.0<z / H<1.0)$ のみを示している。

Fig.7 Instantaneous vector and contour of $x z$ cross section at $y / H=0.5$ and (b) instantaneous vector* at the first grid from the front wall of the target block and contour of the wall pressure. * Only shown in the area between two blocks $(0.0<x / H<2.0,0.0<z / H<1.0$.

$(\mathrm{a}-1)$
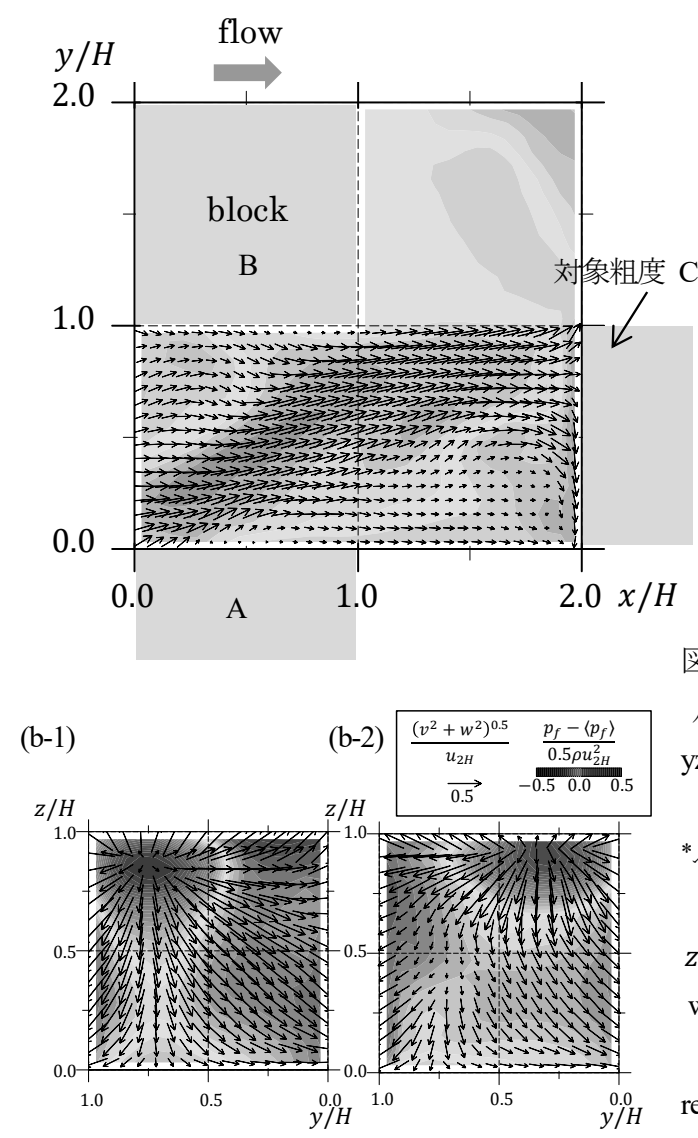

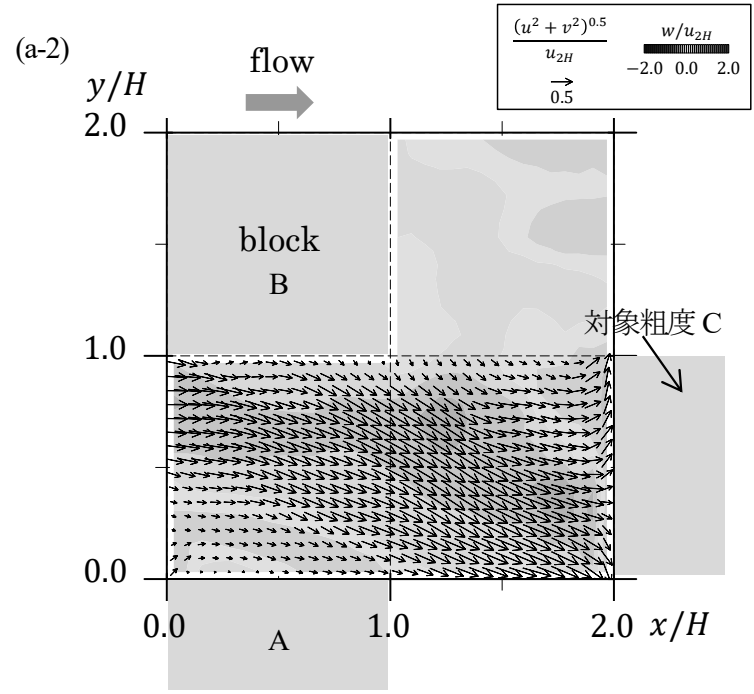

図 8 千鳥配列の (a) $z / H=0.5$ における xy断面の速度ベクト ル゙と鉛直方向風速 (b) 対象粗度風上面の最近傍格子における yz 断面の速度ベクトルと瞬時前面壁面圧力 (a-1) と(b-1) , (a-2) と(b-2) はそれぞれ同じ時刻における結果を示している。

*ベクトルは粗度間 $(0.0<x / H<2.0,0.0<y / H<1.0)$ のみを表示している。

Fig.8 (a) instantaneous vector ${ }^{*}$ and contour of xy cross section at $z / H=0.5$ and (b) instantaneous vector at the first grid from the front wall of the target block and contour of the instantaneous wall pressure.

(a-1) and (b-1), (a-2) and (b-2) are the data at the same time step, respectively. ${ }^{*}$ Only shown in the area between two blocks $(0.0<x / H<2.0,0.0<$ $y / H<1.0)$. 
おける空間差圧と最近傍格子における速度べクトルを 示している. なお, 図8 について, (a-1)と(b-1), (a-2)と (b-2) は同じ時刻における結果である。粗度風上面左上部 で大きな圧力となる図 8(a-1) では, 粗度 A に衝突した流 れが粗度 $\mathrm{AB}$ 間に入り込むことによって, 対象粗度 $\mathrm{C}$ の $y / H=1$ 付近に向かって速い流れが発生し, 粗度 $\mathrm{C}$ の風 上面に衝突している様子がわかる。図 $8(\mathrm{a}-2)$ では逆向き の流れが形成され, 粗度 Bによって気流が粗度間に導入 され, 対象粗度 $\mathrm{C} の y / H=0$ 付近に向から流れが発生 している。従って, 千鳥配列においても風上側に位置す る粗度により気流が左右に切り替わることに対応して, 壁面圧力も間欠的に大きな值となることがわかる。また， 整形配列の場合に比べてキャニオン内流速が大きいこと から, 千鳥配列の抗力係数が整形配列よりも大きくなる のは, 空気の導入に伴い発生する大きな形状抵抗に依る ものだと推測される。

\section{4 平均壁面圧と周辺気流の関係}

これまでに示した瞬時速度分布および粗度風上面圧力 分布の相関関係について，本節では定量的な評価を行う ため, 壁面風圧とある地点における風速との相関係数を 算出する。風速と圧力の相関係数は, 次式により定義す る。

$$
R_{p u_{i}}\left(x^{\prime}\right)=\frac{\overline{p_{f}^{\prime}\left(y_{r}, z_{r}, t\right) u_{i}^{\prime}\left(x^{\prime}, y_{r}, z_{r}, t\right)}}{\sigma_{p f} \sigma_{u_{i}}}
$$

ここで， $x_{r}, y_{r}, z_{r}$ は粗度風上面上の基準点における座 標, $x^{\prime}$ は, 粗度風上面を 0 とした主流方向距離と定義す る $\left(x^{\prime}=x-x_{r}\right)$ 。すなわち, 相関係数 $R_{p u_{i}}$ は, 壁面上 に定義した基準点における圧力 $p_{f}$ と, 主流風上方向に $x^{\prime}$ 離れた場所における速度 $u_{i}$ の二点相関係数に相当寸る。 図 9 (a), (b) には，整形配列と千鳥配列における二点の定 義点 $\mathrm{A}, \mathrm{B}$ に対する相関係数の主流風上方向変化を示し ている。

整形配列の場合，大きな壁面圧力が観られた粗度風上 面外縁上の基準点 A $\left(x_{r}=2.0 H, y_{r}=0.5 H, z_{r}=1.0 H\right)$ および基準点 $\mathrm{B} \quad\left(x_{r}=2.0 H, y_{r}=0.0 H, z_{r}=0.5 H\right)$ に おける相関係数を示した。図 9 (a) の基準点 $\mathrm{A}$ では，壁面 近傍において壁面圧力が主流方向風速と強い正の相関を もち, 最大で $R_{p u}=0.8$ 程度の相関係数を示し, 風上方 向に対して徐々に減少寸る。一方，鉛直方向の相関係数 $R_{p w}$ は強い負值を示し, 風上方向に対して徐々に増加し ていることがわかる。一方で，スパン方向気流との相関 係数 $R_{p v}$ は壁面からの距離に依らずほぼ 0 である。正の 相関係数に対しては, $p_{f}^{\prime}>0$ かつ $u_{i}^{\prime}>0$ および $p_{f}^{\prime}<0$ かつ $u_{i}^{\prime}<0$ となる二つの場合が考えられることから，
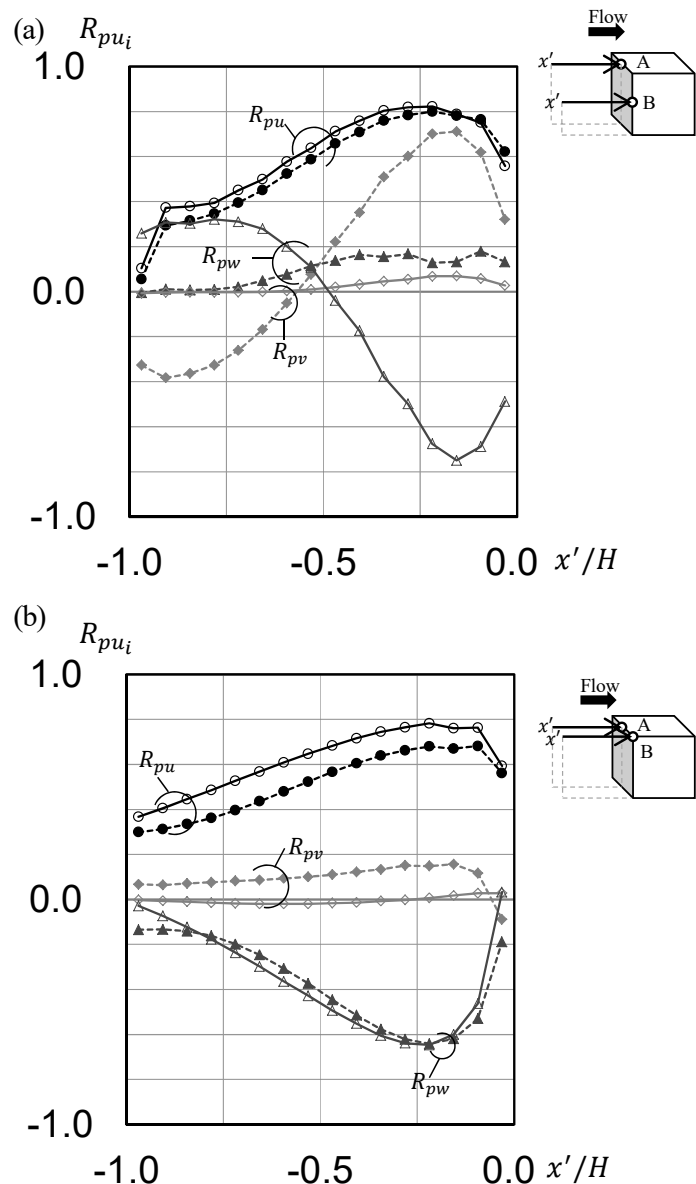

図 9 圧力・風速相関係数と壁面からの距離.(a) SQ, 実 線: A 点 $\left(x_{r}, y_{r}, z_{r}\right)=(2.0 H, 0.5 H, 1.0 H)$, 破線: $\mathrm{B}$ 点 $\left(x_{r}, y_{r}, z_{r}\right)=(2.0 H, 0.0 H, 0.5 H)$ (b) ST, 実線: A 点 $\left(x_{r}, y_{r}, z_{r}\right)=(2.0 H, 0.5 H, 1.0 H)$, 破線: B 点

$$
\left(x_{r}, y_{r}, z_{r}\right)=(2.0 H, 0.0 H, 1.0 H)
$$

Fig. 9 Correlation coefficients between wall pressure and wind speed (a) SQ, solid line: A $\left(x_{r}, y_{r}, z_{r}\right)=$ $(2.0 H, 0.5 H, 1.0 H)$, dashed line: $\mathrm{B}\left(x_{r}, y_{r}, z_{r}\right)=$ $(2.0 H, 0.0 H, 0.5 H)$ (b) ST, solid line: A $\left(x_{r}, y_{r}, z_{r}\right)=$ $(2.0 H, 0.5 H, 1.0 H)$, dashed line: $\mathrm{B}\left(x_{r}, y_{r}, z_{r}\right)=$ $(2.0 H, 0.0 H, 1.0 H)$

主流方向風速 $u$ に対しては, 壁面に接近寸る気流によっ て壁面圧力が増加する場合と, 平均流よりも遅い流れが 発生する際に壁面圧力が低下寸る場合が存在する。従っ て, 基準点 A においては, 粗度上空をかす好 Skimming Flow のような気流場が形成され，間欠的に上空風がキャ ニオン内に取り込まれることによりキャニオン内に平均 
流よりも速い下降流が生じる際に大きな壁面圧力が作用 することと, 空気塊がキャニオン内に取り込まれにくく なることで, 主流方向流や鉛直下降流が平均值よりも小 さくなるために壁面風圧も小さくなることの両方が重畳 されて圧力は主流風速と正相関, 鉛直風速とは負相関と なったのだと考えられる。

また，粗度風上面の側部中央に相当する基準点 $\mathrm{B}$ にお いては, 主流方向速度とは基準点 $\mathrm{A}$ と同じように, 壁面 近傍で大きな相関係数 $R_{p u}$ を示し, 主流風上方向に対し て減少していることがわかる。それに対して基準点 $\mathrm{A}$ と 異なるのは, 鉛直方向気流との相関 $R_{p w}$ が距離に依らず 非常に小さくなる一方で，スパン方向気流との相関 $R_{p v}$ が壁面近傍で大きな值を示していることである。これら のことは, 風上から見通せる街路における風速の速い主 流が, 粗度間に導入されることでスパン方向の気流が発 生し正の鉛直方向渦度をもつ渦が形成されることに応じ て, 粗度風上面側部における壁面圧力が大きな值を示す ことを示唆している。その一方で，スパン方向からの空 気塊の取り込みが弱く平均流速よりも主流やスパン方向 気流の速度が小さくなる場合には, 壁面風圧も平均值に 比べて小さな值を示すことが予想される。

千鳥配列においては, 壁面圧力が大きくなる点として, 基準点 $\mathrm{A}\left(x_{r}=2.0 H, y_{r}=0.5 H, z_{r}=1.0 H\right)$ と基準点 $\mathrm{B}$ $\left(x_{r}=2.0 H, y_{r}=1.0 H, z_{r}=1.0 H\right)$ の二点おける風上方 向相関係数を示した。いずれの基準点においても, 壁面 からの距離に依らずスパン方向気流との相関 $R_{p v}$ は非常 に小さいが, 壁面近傍において主流方向気流との相関 $R_{p u}$ は正となり, 鉛直方向気流との相関 $R_{p w}$ は負值を示す。 これは, 千鳥配列では粗度上空風がキャニオン内に導入 されることで壁面圧力が大きくなることを意味しており， 上空からキャニオン内に空気が導入される瞬時気流場を 良く説明する結果となっている。

先述のとおり, 相関係数の絶対值が大きくなる場合に は, 壁面風圧に作用する周辺気流場として壁面圧力を増 加させる $\left(p_{f}^{\prime}>0\right)$ 場合と, 減少させる場合 $\left(p_{f}^{\prime}<0\right)$ の両方が考えられる。そこで, 大きな相関係数が見られ た $x^{\prime}=0.1 H$ の点における相関係数に対して, 四象限解 析 ${ }^{11)}$ 適用し, 気流場の性質と壁面圧力の関係について 考察する。四象限解析では, 壁面変動圧力 $p_{f}^{\prime}$, と風速 $u_{i}^{\prime}$ の 符号に応じて, 以下に定義する寄与率 $D_{p u_{i}}^{n}(S)$ を算出す る。

$$
D_{p u_{i}}^{n}(S)=\frac{1}{T \sigma_{p f} \sigma_{u_{i}}} \int_{T} p_{f}^{\prime} u_{i}^{\prime} I_{S}^{n} d t
$$

ここで, $T$ は観測時間を示す。 $n$ は, 各象限 (第一象 (a)

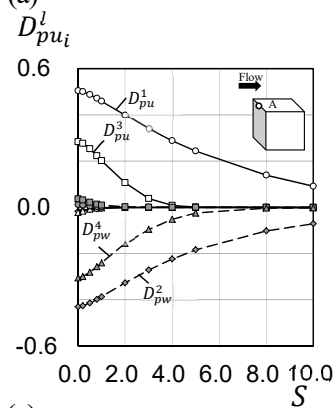

(c)

$D_{p u_{i}}^{l}$

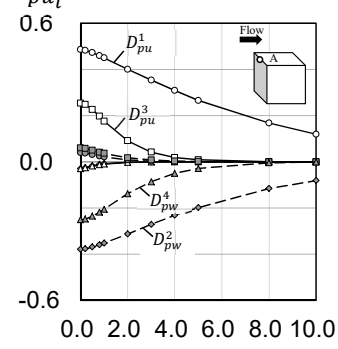

(b)

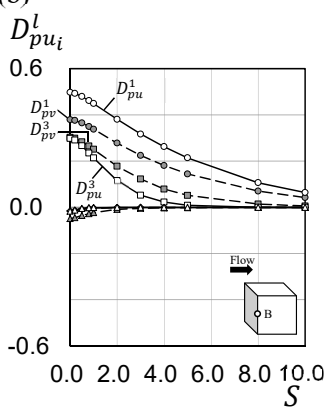

(d)

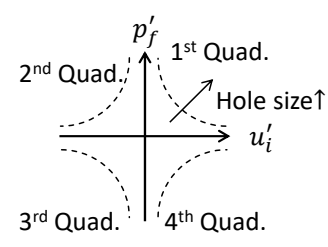

図 10 四象限解析.(a) $\mathrm{SQ},\left(x^{\prime}, y_{r}, z_{r}\right)=$ $(0.1 H, 0.5 H, 1.0 H)$, 実線: $D_{p u}^{l}$, 破線: $D_{p w}^{l},(\mathrm{~b}) \mathrm{SQ}$, $\left(x^{\prime}, y_{r}, z_{r}\right)=(0.1 H, 1.0 H, 0.5 H)$, 実線: $D_{p u}^{l}$, 破 線: $D_{p v}^{l}$, (c) ST, $\left(x^{\prime}, y_{r}, z_{r}\right)=(0.1 H, 0.5 H, 1.0 H)$, 実 線: $D_{p u}^{l}$, 破線: $D_{p w}^{l}$. $\bigcirc$ :第一象限 $\searrow$ : 第二象限 $\square$ : 第三象 限 $\triangle$ : 第四象限 (d) 概念図

Fig.10 Quadrant analysis (a) SQ, $\left(x^{\prime}, y_{r}, z_{r}\right)=$ $(0.1 H, 0.5 H, 1.0 H)$, Solid line: $D_{p u}^{l}$, Dashed line: $D_{p w}^{l}$, (b) SQ, $\left(x^{\prime}, y_{r}, z_{r}\right)=(0.1 H, 1.0 H, 0.5 H)$, Solid line: $D_{p u}^{l}$, Dashed line: $D_{p v}^{l}$, (c) ST, $\left(x^{\prime}, y_{r}, z_{r}\right)=$ $(0.1 H, 0.5 H, 1.0 H)$, Solid line: $D_{p u}^{l}$, Dashed line: $D_{p w}^{l}$. $\bigcirc: 1^{\text {st }}$ Quadrant, $\diamond: 2^{\text {nd }}$ Quadrant, $\square: 3^{\text {rd }}$ Quadrant, $\triangle: 4^{\text {th }}$ Quadrant, (d) Schematics of Quadrant analysis

限: $p_{f}^{\prime}>0, u_{i}^{\prime}>0$, 第二象限: $p_{f}^{\prime}>0, u_{i}^{\prime}<0$, 第三象限: $p_{f}^{\prime}<0, u_{i}^{\prime}<0$, 第四象限: $p_{f}^{\prime}<0, u_{i}^{\prime}>0$, 図 10 (d) 参照), $S$ はホールサイズを表している。ホールサイズ $S$ は, 次 式定義される $I_{S}^{n}$ に含まれるパラメータで, 観測点におけ る相関項の大きさ $\left|\overline{p_{f}^{\prime} u_{i}^{\prime}}\right|$ に対する倍率を意味している。 $I_{S}^{n}$ $=\left\{\begin{array}{ccc}1 & \text { if }\left|p_{f}^{\prime} u_{i}^{\prime}\right|>S\left|\overline{p_{f}^{\prime} u_{i}^{\prime}}\right| \text { and } \mathrm{n}^{\text {th }} \text { quad. } \\ 0 & \text { otherwise }\end{array}\right.$

以上の定義から, $p_{f}^{\prime}$ とu 第一, 第三象限の寄与が他に比べて大きく, 負相関の場 合は, 第二, 第四象限の寄与が大きくなる。また, ホー 
ルサイズ $S$ に対する寄与率 $D_{p u_{i}}^{n}(S)$ の変化を調べること で，ある時刻における $p_{f}^{\prime}$ とu ${ }^{\prime}$ の積の大きさが，相関 項の大きさ $\left|\overline{p_{f}^{\prime} u_{i}^{\prime}}\right|$ に対して $S$ 倍以上となるような $p_{f}^{\prime}$

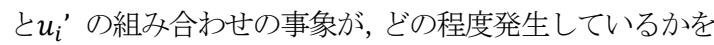
判断することができる。すなわち，平均から離れた大き な風速 $u_{i}^{\prime}$ や变動圧力 $p_{f}^{\prime}$ が相関係数に対して影響してい るかどうかを調心゙ることが可能となる. ホールサイズ $S$ の值は， $S$ に対する定性的な傾向を見る目的で， 0 から 10 としている。

図 10 (a)(b) には，整形配列において，基準点を A，B とした場合の壁面からの主流方向距離 $x^{\prime}=0.1 H$ にお ける相関係数について, 四象限解析を適用した結果を示 した。基準点 $\mathrm{A}$ においては， $x^{\prime}=0.1 H$ における相関係 数は $R_{p u}=0.75, R_{p w}=-0.69$ であるため, 主流 $u$ に ついては第一象限 $D_{p u}^{1} \quad\left(p_{f}^{\prime}>0, u^{\prime}>0\right)$ と第三象限 $D_{p u}^{3}$ $\left(p_{f}^{\prime}<0, u^{\prime}<0\right)$, 鉛直流については第二象限 $D_{p w}^{2}$ $\left(p_{f}^{\prime}>0, w^{\prime}<0\right)$, 第四象限 $D_{p w}^{4} \quad\left(p_{f}^{\prime}<0, w^{\prime}>0\right)$ の寄与が大きくなっており, それ以外の象限の寄与は極 めて小さい。また, ホールサイズ 0 の条件において, $D_{p u}^{1}>$ $D_{p u}^{3}$ および $D_{p w}^{2}<D_{p w}^{4}$ であることから, 粗度上空風のキ ヤニオン内導入により, 平均速度よりも速い接近流と鉛 直下降流が形成されることと壁面圧が増加することが強 く相関していることを示している。すなわち, 壁面風圧 に対して大きく寄与する現象は，平均よりも遅い流れに よる壁面圧力の低下よりも，接近流による圧力増加であ るといえる。さらに, ホールサイズ の増加に対して, $D_{p u}^{3}, D_{p w}^{4}$ は, $S \sim 4$ 程度でほとんどその寄与がなくなる のに対して, $D_{p u}^{1} ， D_{p w}^{2}$ の寄与はS 10 においても見ら れる。従って, 非常に強い主流方向流れとそれに伴う下 降流が，突発的に大きな壁面圧力を引き起こしているこ とが予想される。基準点 $\mathrm{B}$ においては, 街路部分におけ る速い主流方向流れがスパン方向に取り込まれることに より，壁面圧力と主流およびスパン方向気流との相関係 数がいずれも正 $\left(R_{p u}=0.76, R_{p v}=0.61\right)$ となるため, 第一象限 $D_{p u_{i}}^{1}\left(p_{f}^{\prime}>0, u_{i}^{\prime}>0\right)$, 第三象限 $D_{p u_{i}}^{3} \quad\left(p_{f}^{\prime}<0\right.$, $\left.u_{i}^{\prime}<0\right)$ の寄与が支配的になっている。それに加えて, 基準点 $\mathrm{A}$ の場合と同様に，いずれも第一象限の寄与 $D_{p u_{i}}^{1}$ が大きく，ホールサイズS に対する減少率も小さい。こ のことから, 街路における風速の大きな主流方向気流が 取り込まれることによって, 間欠的な壁面圧力の増加を 引き起こしていることが予想される。

千鳥配列については, 基準点 $\mathrm{A}$ において, 主流方向気 流の導入により鉛直流が発生することに対応して，壁面
圧力と主流方向気流が正相関，鉛直気流が負相関となっ ているため, 寄与率で観ると主流方向については第一 $D_{p u}^{1}$ $\left(p_{f}^{\prime}>0, u^{\prime}>0\right)$, 第三 $D_{p u}^{3} \quad\left(p_{f}^{\prime}<0, u^{\prime}<0\right)$, 鉛直 方向ついては第二 $D_{p w}^{2} \quad\left(p_{f}^{\prime}>0, w^{\prime}<0\right)$, 第四象限 $D_{p w}^{4}$ $\left(p_{f}^{\prime}<0, w^{\prime}>0\right)$ の寄与が大きくなっている。加えて, 整形配列の鉛直流取り込みの場合と同様に，ホールサイ ズの増加に対して, 接近流とそれによる下降流を示寸 $D_{p u}^{1}$, $D_{p w}^{2}$ の減少傾向が小さく, 速い主流の衝突が壁面圧増加 の要因になっていることが理解できる。

\section{4.おわりに}

立方体粗度により形成される都市乱流境界層を対象と した LES を実施し，壁面風力換気のポテンシャルである 壁面圧力が，周辺粗度により形成される都市特有の非定 常場および非一様な気流場により強く影響されているこ とを定量的に示した。結論は以下の通りにまとめられる。 まず，妥当性検証を目的として，速度プロファイル，抗 力係数, 形状抵抗比について, 既往研究により得られた 風洞実験結果と本結果を比較した。形状抵抗比が十分大 きくなる千鳥配列については, 本解析程度の空間解像度 であっても風洞実験をかなり高く再現出来ることを示し た。次に，各配列における壁面風圧分布を統計值と瞬時 気流分布により分析し，周辺粗度により形成される定常 気流場・非一様な気流場が壁面風圧に影響していること を確認した。特に, 整形配列においては, 粗度風上面の 側面に位置する街路領域からの取り込みや上空をかすめ る Skimming Flowによって, 粗度風上面外縁に沿って壁 面風圧が高くなることが示された。一方，千鳥配列にお いては, 前方粗度の影響により側面からの取り込みはほ とんど無く, 粗度側面での壁面圧は大きくならないが, キャニオン内に取り込まれる主流の影響により, 粗度風 上面上部で大きな圧力分布を示す。また，これらの瞬時 気流場と圧力分布が，統計的に関係性があることを，相 関係数分布を算出することで定量的に示した。最後に， 四象限解析法を相関係数について適用寸ることで，相関 係数を各象限に分類し，それに加えてホールサイズを導 入することで，強度に関する分類を行った。その結果， 整形配列では, 速い主流が強い下降流を引き起こすこと, や，強い粗度側面からの気流の取り込みが大きな壁面圧 を引き起こしていることが示された。千鳥配列において は，上空からの速い主流がキャニオン内に取り込まれる ことにより，大きな壁面風圧が発生していることがわか った。

本論では, 建物群による非定常気流場のみを解析とし， 
非定常換気量に寄与する風圧係数の時間変動に, どのよ うな建物周辺気流場が影響を及ぼしているかを明らかに することができた. 今後は, 粗度群周辺気流に加えて, 換気量推定を行う対象建物の室内側気流を同時解析する coupling simulation を行い, 実際の非定常換気量と変動風 圧係数から推定される換気量を相互比較することで, 建 物群内に位置する対象建物の非定常換気量推定方法につ いて検討寸る予定である.

\section{謝辞}

この研究は，KAKENHI 15K14078 の助成を受けた。以 上に表して謝意を表する。また, 本論文は平成 26 年度風 工学会優秀修士論文賞を受賞した論文に基づき, 内容を 再構成したものである。

\section{参考文献}

1) 建築環境工学, 浦野良美, 中村洋, 森北出版, (1996)

2) Jiang, Y., Alexander, D., Jenkins, H., Arthur, R., Chen, “Q. Natural ventilation in buildings: Measurement in a wind tunnel and numerical simulation with large-eddy simulation", J Wind Eng Ind Aerodyn 91, pp.331-353, (2003)

3) Hu, C.H., Ohba, M., Yoshie, R., "CFD modelling of unsteady cross ventilation flows using LES”, J. Wind Eng. Ind. Aerodyn. 96, pp.1692-1706, (2008)

4) Oke, T.R., "Street design and urban canopy layer climate", Energ. Build. 11, pp.103-113, (1988)

5) 丸山敬, 立方体粗度ブロックの配列形状の違いのよ る抗力の変化について, 日本風工学会誌 49, pp.15-24, (1991)

6) 萩島理, 谷本潤, 永山浩二, 古賀正浩, 高さの分布 のある立方体粗度群の抗力係数に関寸る風洞実験, 日本建築学会環境系論文集第 619 号, pp.39-45, (2007)

7) 久保田徹, 三浦昌生, 富永禎秀, 持田灯, 実在する $270 \mathrm{~m}$ 平方の住宅地における地域的な風通しに関す る風洞実験, 日本建築学会計画系論文集, 第 529 号, pp.109-116, (2000)

8）義江龍一郎, 田中英之, 白澤多一, 小林剛, 高層密 集市街地における建物群の形態が歩行者レベルの風 速・気温分布に与える影響, 日本建築学会環境系論 文集第627 号，pp.661-667，(2008)

9) Razak, A.A., Hagishima, A., Ikegaya, N., Tanimoto, J., "Analysis of airflow over building arrays for assessment of urban wind environment", Build Environ 59, pp56-65,
(2013)

10) Ikegaya, N., Ikeda, Y., Hagishima, A., Razak, A.A., Tanimoto, J., "A prediction model for wind speed ratios at pedestrian level with simplified urban canopies", Theoretical Applied Climatolgy, online First, (2015)

11) Raupach, M.R., "Conditional statistics of Reynolds stress in rough-wall and smooth-wall turbulent boundary layers", J. Fluid Mechanics 108, pp.363-382, (1981)

12) Finnigan, J.J., Shaw, R.H., Patton, E.G., "Turbulence structure above a vegetation canopy”, J Fluid Mechanics 637, pp.387-424, (2009)

13) Coceal, O., Dobre, A., Thomas, T.G., Belcher, S.E., "Structure of turbulent flow over regular arrays of cubical roughness", J Fluid Meachanics 589, pp.375-409, (2007)

14) Michioka, T., Sato, A., Takimoto, H., Kanda, M., "Large-eddy simulation for the mechanism of pollutant removal from a tow-dimensional street canyon", Boundary-Layer Meteorol 138, pp.195-213, (2011)

15) 池谷直樹, 萩島理, 谷本潤, 立方体粗度群床面-大気 間のスカラー輸送現象に関する LARGE-EDDY SIMULATION, 日本建築学会環境系論文集 76 (668), pp.943-951, (2011)

16) Versteeg, H.K., Malalasekera, W., "An introduction to computational fluid dynamics", $2^{\text {nd }}$ edition, Pearson Education, pp.193,(2007)

17) Coceal, O., Thomas, T.G., Castro, I.P., Belcher, S.E., "Mean flow and turbulence statistics over groups of urban-like cubical obstacles", Bound-Layer Meteorol. 21, pp.491-519, (2006)

18) Xie, Z., , Castro, I.P., "LES and RANS for turbulent flow over arrays of wall-mounted obstacles" Flow Turb Combust 76, pp.291-312, (2006)

19) Cheng, H., Castro, I.P., "Near wall flow over urban-like roughness", Bound-Layer Meteorol. 104, pp.229-259, (2006)

20) Ikegaya, N., Hirose, C., Hagishima, A., Tanimoto, J., Effect of turbulent flow on wall pressure coefficients of block arrays within urban boundary layer, Build Environ. 100, pp.28-39, (2016)

21) Snyder, W.H., Castro, I.P., "The critical Reynolds number for roughwall boundary layers" Wind Eng. Indust. Aerodyn. 90, pp.41-54, (2002)

22) Zaki, S.A., Hagishima, A., Tanimoto, J., "Experimental study of wind-induced ventilation in urban building of 
cube arrays with various layouts", J. Wind Eng. Ind. Aerodyn. 103, pp.31-40, (2012)

23) Leonardi, S., Castro, I.P., "Channel flow over large cube roughness: a direct numerical simulation study", J Fluid
24) Mech. 651, pp.519-539, (2010)

25) Cheng, H., Hayden, P., Robins, A.G., Castro, I.P., "Flow over cube arrays of different packing densities" Wind Eng. Indust. Aerodyn. 95, pp.715-740, (2006) 